\title{
Brain Drain in Higher Education. The Impact of Job Stress and Workload on Turnover Intention and the Mediating Role of Job Satisfaction at Universities
}

\author{
Rao Tahir Anees, Petra Heidler, Luigi Pio Leonardo Cavaliere, Nordiana Ahmad Nordin
}

\section{ABSTRACT}

This study seeks to determine the impact of job stress and workload on turnover intention along with the mediation role of job satisfaction. A total of 140 academics and management personnel participated in this study's survey. A partial least square structural equation modeling was used for data analysis. The results show that job stress and workload have a positive effect on turnover intention, while job satisfaction mediates the relationship between job stress, workload, and turnover intention. Future research could adapt and adopt the herein used methodology and research topic to other countries or in other industries.

Keywords: Turnover Intention, Job Stress, Workload, Job Satisfaction.
Submitted : April 12, 2021

Published : May 03, 2021

ISSN: $2507-1076$

DOI: $10.24018 / \mathrm{ejbmr} .2021 .6 .3 .849$

Rao Tahir Anees*

Post Graduate Centre, Limkokwing University of Creative Technology, Cyberjaya, Malaysia.

(e-mail: aneesrao82@gmail.com)

Petra Heidler*

Department of International Business and Export Management, IMC University of Applied Sciences, Krems, Austria.

(e-mail: petra.heidler@fh-krems.ac.at)

Luigi Pio Leonardo Cavaliere

Dipartimento di Economia, Università di

Foggia, Foggia, Italy.

(e-mail: luigi.cavalie@gmail.com)

Nordiana Ahmad Nordin

Faculty of Economics and Business,

University Malaysia, Sarawak, Malaysia.

(e-mail: annordiana@ unimas.my)

*Corresponding Author

\section{INTRODUCTION}

Human resources are one of the core assets of any organization. In today's competitive world, organizations struggle to keep and retain their employees. To increase productivity, organizations are under tremendous pressure to satisfy and retain staff. The departure of trained and dedicated employees is a great loss to the organization. High turnover and brain drain have been identified as some of the main problems facing especially universities, including in Malaysia. Qualified and competent academic staff are leaving higher education institutions to work outside their country of birth and Africa [1]-[3]. However, the resignation of employees negatively affects the effectiveness and performance of the organization. Therefore, effective managers should always research the reasons for leaving and seek solutions to retain their best employees. Yet, for multiple reasons, employee turnover is common in organizations. The current body of literature shows that job satisfaction greatly reduces employee turnover rate [4].

Due to the nature of this problem and its direct impact on organizational performance, researchers often attempt to explore factors impacting employee turnover. Understanding these mechanisms is important, because only by fully understanding the process of how turnover occurs, can employers' steps to reduce said turnover. However, current studies do not specifically study the mechanisms by which pressure and work input affect rotation intention. We believe that the relationship between job pressure, job commitment, and turnover intention is likely to be an indirect relationship in the organization through job satisfaction. Therefore, this study specifically investigates how job satisfaction in organizations can reconcile the relationship between job stress, job participation, and turnover intention in Malaysian universities.

\section{LITERATURE REVIEW}

\section{A. Turnover Intention}

In current literature, the intention of resignation and the intention of resignation and resignation or the intention of resignation can be expressed interchangeably. Employee resignation generally includes three stages: Resignation thought, job search, and intention to resign [5]. The most important precursor to resignation behavior is the intention to quit. The intention to leave is a measure of the employee's intention to remain in the hiring organization, the employee's tendency to leave the hiring organization, and the employee's 
willingness to consciously and intentionally leave work [6].

Resignation in itself consists of psychological, cognitive, and behavioral aspects. Tett and Meyer [7] defined resignation as "the termination of an individual's work in a given company," and defined resignation intention as "the last of a series of exit perceptions, that is, a set of intentions in the ones to think about and find the way out". In general, the intention to leave has become the most important sign of leaving. A review of the literature by Bluedorn [8] cited 23 studies that reported a significant positive correlation between an intention to leave and actual exit behavior. Employees create efficiency and effectiveness by cultivating stable organizational relationships, and they will stay long enough to get acquainted with their customers, suppliers, and colleagues, and become more stable. Research by Kim and Fernández [9] shows that personal factors affect the intention to stay or leave an organization. The resignation of employees is a very complicated matter, as it is a private and personal decision of an individual within a larger organization. [10]. Hancock et al. [11] state that employees generally need a period of reflection before making the final decision to leave; this is the so-called intention to leave. Scanlan and Still [12] add that internal drive is a work-related factor that encourages people to stay, while external drive is a work-related factor that encourages people to leave the organization. External attraction can be described as various factors that attract a person to another job, while external attraction is a factor that has nothing to do with work and can encourage a person to leave, such as personal commitment [13]. Turnover intention contributes to detrimental influences on the company such as costs incurred in the recruiting phase, training, psychological confusion of other employees and lower affinity for the organization [14]. Thus, a higher turnover rate will bring high costs and huge losses to the higher education system, especially after outstanding academics leave. This is business critical as it is difficult to replace qualified human resources. According to Dipboye [15], several indicators to measure the intention of leaving are:

1. Thinking of quitting: Employees consider leaving or staying in the work environment. Start with the employee's dissatisfaction with the job and then the employee considers leaving the workplace.

2. Intention to search for alternatives: This reflects the desire of the individual to find work in other organizations after the employee has started considering quitting and is trying to find a new job.

3. Intention to quit: This is someone who intends to leave; and if they find a better job, employees tend to resign.

\section{B. Job Stress}

According to Badeni [16], stress is the feeling of discomfort, anxiety, and anxiety that can cause bad thoughts and emotions, and can even impact an employee's physical conditions. Stress can also be defined as a response that can easily adapt to the external environment, which can lead to psychological, behavioral, and physical deviation of the members of an organization. Evidence shows that there is a positive correlation between job stress caused by role ambiguity and turnover rate [17]. Contrary to this, research shows that there is no obvious pressure conversion relationship, especially when using samples from different cultural origins. In recent years, discomfort in the workplace has been gradually considered as one of the stressors in the workplace [18], [19]. Increased workload and other factors can put pressure and discomfort on employees that affect performance. Stress is an uncomfortable emotional state that occurs when a person is not convinced of their ability to overcome significant perceptual challenges [20]. Petrus et al. [21] believe that work stress is a state of tension that affects people's emotions, thought processes and physical conditions. According to the research of Davis and Newstrom [22], work stress is caused by an excessive workload, limited work hours, lack of adequate responsibilities, and value differences with the company. Work stress can also be defined as respondents' perceptions of various work-related conditions and the level playing field of employees [23]. The impact of work pressure on employee performance is a factor worth considering, as these factors can cause discomfort to employees at work, reducing productivity and causing employees to consider moving to another company. Sugiyanto and Irawati [24] propose that physical fatigue can lead to work-family conflicts among employees. If this situation continues to occur, the desire to move will become stronger. Both Beehr [25] and Suharnomo [26] point out that stress is a situation that forces someone to leave due to psychological or physiological changes, and this situation forces the person to deviate from their normal functions. Some indicators that affect work stress are:

1. Psychologically: Prolonged stress will affect people negatively.

2. Physically: Employees will feel tired from being overworked.

3. Behavioral: Employees will engage in unpleasant behaviors during work hours.

Syahronica and Ruhana [27] state that stress is the main factor of turnover intention, which is consistent with other research of Manurung and Ratnawati [28] that stress has a positive effect on turnover intention the employees:

\section{Hla: Job stress is negatively associated with turnover intention.}

Every employee spends a significant amount of hours in the workplace, and the workplace atmosphere can have a profound impact on one's personal life. The concept of stress is a multidimensional, and it may be interpreted from two major perspectives: eustress and distress. Stress has been conceptualized differently in literature. Yet exhaustion, psychological strain, emotional distress, physical illness all occurs due to extreme levels of stress in the workplace. Syele [29] defines this as a psychological reaction to certain threatening environmental events, while Riggio [30] states that it is a physiological and/or psychological reaction to events that are perceived to be threatening. In the case of this present research, work-related stress is conceptualized as physiological stress (PHS) and psychological stress (PSS) in carrying out the duties and responsibilities to achieve key performance indicators [31]-[33]. The PHS reactions of the body (i.e., abdominal pain, chest pain, fatigue, headache, lethargic, migraine, and sleep disturbance) to various stressful triggers at the workplace can directly and negatively affect an individual's productivity, effectiveness, quality of work, and 
personal health [34]-[36]. In juxtaposition to this, PSS refers to the internal pressure an employee feel [37] due to substantial influence from internal and external environment [38]-[40] that result in an imbalance of one's feelings and senses, which in turn contributes to an inability to cope with work and pressure in the workplace. It is also important to note that stress in turn creates serious psychological stress in the workplace and long-term sickness [41]. People with PSS tend to behave irrationally and are emotionally deficient [42], which ultimately affects their performance level. The better an organization is able to clear the workplace from stress and develop a positive attitude towards its work and to create the right conditions for job satisfaction, the better it can achieve its goal of high productivity and efficiency. Job satisfaction is one of the most challenging organizational concepts and the basis of many management policies to increase organizational productivity and efficiency. While problem avoidance strategies are often associated with symptoms of depression and high levels of self-reported aggressive behavior and anxiety [43]. Depressed individuals with high attachment experience higher levels of stress [44]. There is a negative correlation between anxiety attachment and job satisfaction. That is, the higher the stress level, the less job satisfaction. Job stress can predict job satisfaction. Selfcontrol is the only component of emotional intelligence that plays an important role in projecting job satisfaction [45]:

H1b: Job stress is negatively associated with job satisfaction.

\section{Workload}

Workload is a multidimensional concept that considers time, mental tasks, physical tasks, and stressors. It can be used to plan a workforce, assign duties, and assess the impact of work practices on operator efficiency and health [46]. According to Arshad and Tham [47], [48], work stress can have a negative impact on the health of employees due to excessive stress, thus leading many employees to change jobs. This is also the result of the work environment, including the skills and behaviors of employees, the workplace, and the perceptions of workers. A cooperative work environment based on an organizational culture of support and teamwork can be encouraging and reduce job stress [49]. According to Masta and Riyanto [50], workload is defined as a working condition, and the job description needs to be completed in a short time. Previous research by Rizka [51] along with Suarthana and Riana [52] found that workload has a significant impact on turnover intention. Tulangow [53] also found that workload has a great influence on turnover intention. According to Hart et al. [54], the workload is generated by the interaction between the requirements of the task, the work environment used as a workplace, the skills, attitudes, and perceptions of the employee. Sometimes, workload can be operationally defined based on various factors, such as task requirements or work difficulty to complete a job. Workload can be described as the degree of excessive demand for job roles [55]. Xiaoming [56] considers workload as the workload in the work environment that exceeds personal capacity, leading to threats and responses to stress, anxiety, frustration, oppression, or annoyance. This reaction will change the physical and mental condition and behavior of normal people. Zhang and Kumada [57] add that there are three methods for measuring mental load, namely self-report, performance, and physiological methods:

\section{H2a: Workload is negatively associated with turnover intention.}

Job satisfaction can be improved by reconsidering employees' amount of workload, as the excessive workload can reduce employee job satisfaction. The workload is defined as a variety of demands that include quantitative, qualitative, mental, and physical tasks [58]. Workload is one aspect that must be considered by every company, as it is one that can increase employee productivity. Several studies [59], [60] state that workload is a number of activities that require expertise and must be carried out within a certain period in physical or psychological form. Furthermore, it is noted that [61], [62] workload is the average frequency of each job within a certain period. Workload (both physical and mental) can significantly affect job satisfaction, and physical workloads can cause fatigue, work errors, and decreased productivity even over short work periods [63]. However, handling mental workloads is not easy either because it is related to employee mental state [64]:

\section{H2b: Workload is negatively associated with job satisfaction.}

\section{Job Satisfaction as Mediator}

Job satisfaction refers to an emotional state that reflects an emotional response to work and working conditions [65]. Employees often react negatively to work, leading to withdrawal behavior and loss of motivation for job functions [66]. Job satisfaction indicates a person's common behavior toward her profession. People with high job satisfaction have positive behaviors about their work. People who are not satisfied with their profession behave negatively. People with high professional satisfaction have a positive attitude towards their profession, while those who are dissatisfied have a negative attitude towards their profession [67]. Literature points to another possibility of this mixed result, indicating that there is an unexplored mechanism through which job pressure affects employee turnover. In particular, this study examines the possibility that job satisfaction may mediate this relationship with the organization's employees. Previous research shows that different dimensions of job stress will affect employee satisfaction in different ways [68]. On one hand, sources of pressure related to challenges, such as workload and sources of time pressure, can be seen as opportunities for people to obtain work-related development, which in turn can directly lead to work satisfaction. On the other hand, stressors related to barriers, such as role conflict and role ambiguity can be seen as barriers to personal growth, leading to job dissatisfaction [69]. The dissatisfaction of autonomy and relevance (satisfaction of basic psychological needs) has a significant impact on the willingness of employees to leave (intention to resign) [70]. People with high occupational satisfaction have a positive attitude towards the occupation, and those who are dissatisfied have a negative attitude towards the occupation: 


\section{H3: Job satisfaction is negatively associated with turnover intention.}

Ahmad [71] deployed Pearson's correlation and multiple regression analysis to discover that job satisfaction and job stress have a significant negative correlation with the turnover of the textile industry in Pakistan. Employees are more likely to want to leave when they are dissatisfied with being able to influence their job roles and how to perform their duties and have no sense of belonging to the organization. Further prior research also shows that different dimensions of job stress will affect employee satisfaction in different ways [67]. Specifically, not all sources of job stress are closely related to job satisfaction and/or employee dissatisfaction in the workplace [72]. Furthermore, there is a recognized negative relationship between job satisfaction and turnover in organizations [73], [74]. Combining these two conditions, we believe that job pressure has a direct impact on job satisfaction, which can lead to the intention of turnover, which implies that the intermediate relationship between job pressure and the intention of turnover leads to the following final research hypotheses of this empirical study:

\section{H5: Job satisfaction mediates the relationship between job} stress and turnover intention.

H6: Job satisfaction mediates the relationship between workload and turnover intention.

\section{E. Theoretical Framework}

The framework of this study is based on two main variables: job stress and the workload effect on the turnover intention with a mediator job satisfaction. The theoretical foundation of this study is supported by ethical climate theory (ECT). Ethical climates are defined as employees' perceptions of what practices and ethical issues are considered right or wrong in an organization [75]. In fact, ethical climates have been associated with turnover intention in past studies [76].

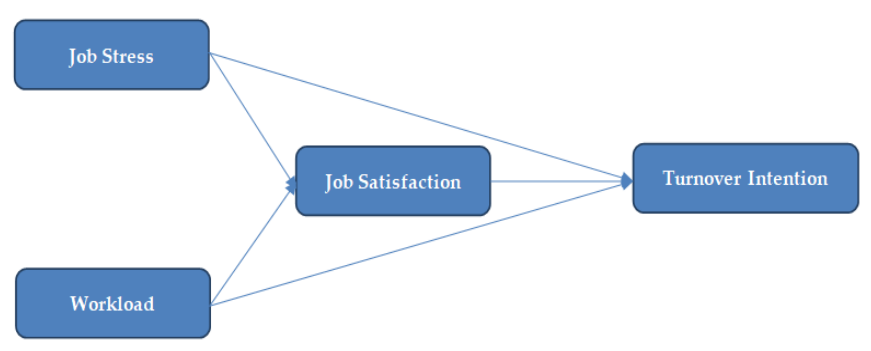

Fig. 1. Theoretical framework.

\section{MethodOLOGY}

This quantitative research study uses questionnaires to collect all utilized data. The deployed questionnaire evaluated work pressure, workload, turnover intention, and job satisfaction as an intermediary effect, and conducted a crosssectional survey using simple random sampling. The target population for this study were professors from four private universities in Malaysia. These included professors, senior lecturers, junior lecturers, tutors, and administrative staff from various departments. The city of Cyberjaya was chosen as the research site because it has multiple private universities. A total of 140 academics and management personnel participated. The questionnaire was delivered manually and online, and participants completed the questionnaire during their free time. The researchers collected the completed questionnaire several days after it was distributed. Partial least square structural equation modeling (PLS-SEM) was used for data analysis in the current study, as proven in similar prior research [77]-[80]. Measurements of all items were achieved using a 5-point Likert scale (ranging from $1=$ "Strongly Disagree" to $5=$ "Strongly Agree").

\section{RESUlTS}

PLS-SEM is a two-step process that involves evaluation measurement and structural models [81], [82]. The model of measurement is part of the entire model in which latent constructs are prescribed. Unobserved variables implied by the covariance between two or more indicators observed are latent constructs. The structural equation modeling of partial least squares was utilized in Smart-PLS to estimate the hypothesis. In past studies, this method has seen widespread use [83]-[85]. PLS-SEM was used for the following reasons: Due to an incremental character of this study, the research focused on the prediction of endogenous variables secondly [86]. First the measurement model should be evaluated by examining the reliability of internal consistency, convergent validity (CV) and discriminant validity (DV) [87]. Internal reliability of consistency measures the extent to which the items measure the latent construct [88], this evaluation was performed by composite reliability (CR) scores. The findings show that all constructs' $\mathrm{CR}$ scores exceeded the 0.700 threshold criterion, demonstrating high internal consistency of the scales used in this study. Next, to evaluate the CV of the constructs, factor loadings and average variance extracted (AVE) were measured. CV is the degree to which a variable is positively associated with alternate measurements of the same construct. The loading factor should be 0.708 or greater, and 0.700 should be deemed similar enough to be appropriate. The threshold value of 0.500 was also met by the AVE scores of all constructs, suggesting an acceptable CV. The factor loadings, CR and AVE scores are presented in Table I DV is another criterion for testing the construct's validity. DV is the extent to which a construct by empirical standards is truly distinct from other constructs DV is tested in this analysis with the aid of Fornell and Larcker's guidelines, which notes that the AVE meaning square root should be greater than the square association with other constructs [89]. The results in Table II show that DV was achieved. 
TABLE I: MEASUREMENT MODEL (FL, CR \& AVE)

\begin{tabular}{cccc}
\hline Latent Variables & $\begin{array}{c}\text { Factor } \\
\text { Loading }\end{array}$ & CR & AVE \\
\hline Job Stress & 0.716 & 0.941 & 0.779 \\
JS 1 & 0.711 & & \\
JS 2 & 0.709 & & \\
JS 3 & 0.778 & & \\
JS 4 & 0.812 & & \\
JS 5 & & 0.869 & 0.736 \\
Workload & 0.702 & & \\
WL 1 & 0.759 & & \\
WL 2 & 0.789 & & \\
WL 3 & 0.757 & & \\
WL 4 & 0.792 & & \\
WL 5 & & 0.909 & 0.719 \\
Job Satisfaction & 0.780 & & \\
JS 1 & 0.723 & & \\
JS 2 & 0.753 & & \\
JS 3 & 0.741 & & \\
JS 4 & 0.745 & & \\
JS 5 & & 0.698 \\
TI 1 & 0.721 & & \\
TI 2 & 0.742 & & \\
TI 3 & 0.732 & & \\
TI 4 & 0.702 & & \\
\hline
\end{tabular}

TABLE II: DISCRIMINANT VALIDITY (FORNELL AND LARCKER CRITERIA)

\begin{tabular}{|c|c|c|c|c|}
\hline Constructs & Job Stress & Workload & $\begin{array}{c}\text { Job } \\
\text { Satisfaction }\end{array}$ & $\begin{array}{l}\text { Turnover } \\
\text { Intention }\end{array}$ \\
\hline Job Stress & 0.882 & & & \\
\hline Workload & 0.641 & 0.857 & & \\
\hline $\begin{array}{c}\text { Job } \\
\text { Satisfaction }\end{array}$ & 0.685 & 0.581 & 0.847 & \\
\hline $\begin{array}{l}\text { Turnover } \\
\text { Intention }\end{array}$ & 0.551 & 0.531 & 0.598 & 0.835 \\
\hline
\end{tabular}

\section{A. Structural Model Assessment}

As proposed by Hair Jr et al. [88], the importance of the indirect impact study was tested next by utilizing the SmartPLS bootstrapping feature. To produce $t$-values and standard errors to validate the statistical validity, a bootstrapping procedure of 5,000 interactions was carried out. Bootstrapping provides no claim as to the sampling distribution of data or the distribution form of variables; in comparison, it can also be used with certainty with a limited sample size. The bootstrapping methodology for indirect impact testing is therefore ideally suited for the PLS-SEM process [90].

TABLE III: DISCRIMINANT VALIDITY (FORNELL AND LARCKER CRITERIA)

\begin{tabular}{ccccc}
\hline Hypothesis & Path & $\begin{array}{c}\text { Path } \\
\text { Coefficient }\end{array}$ & $\begin{array}{c}\mathrm{t}- \\
\text { Statistics }\end{array}$ & $\begin{array}{c}\mathrm{p}- \\
\text { Values }\end{array}$ \\
\hline H1a & $\begin{array}{c}\text { Job Stress } \rightarrow \\
\text { Turnover Intention } \\
\text { Workload } \rightarrow\end{array}$ & 0.421 & 2.780 & 0.000 \\
H1b & $\begin{array}{c}\text { Turnover Intention } \\
\text { Job Stress } \rightarrow \text { Job } \\
\text { Satisfaction }\end{array}$ & 0.325 & 2.182 & 0.002 \\
H2a & $\begin{array}{c}\text { Workload } \rightarrow \text { Job } \\
\text { Satisfaction }\end{array}$ & 0.158 & 2.651 & 0.001 \\
H2b & $\begin{array}{c}\text { Job Satisfaction } \rightarrow \\
\text { Turnover Intention }\end{array}$ & 0.211 & 2.991 & 0.002 \\
H3 & & & & 0.002 \\
\hline
\end{tabular}

\section{B. Mediation Analysis}

Following [88] suggestion, the present research employed SmartPLS bootstrapping function to examine the indirect effect significance to confirm the mediation of Job Satisfaction in the relationship between Job Stress, Workload and Turnover Intention. The values of the specific indirect effect presented in Table IV show that job satisfaction significantly mediates job stress, workload, and turnover intention. If both direct and indirect effects are significant while pointing in the same direction; then, complementary mediation exists [88]. Following this, present research results suggest the existence of partial mediation.

\begin{tabular}{ccccc}
\multicolumn{5}{c}{ TABLE IV: MEDIATION EFFECT } \\
\hline Hypothesis & Path & $\begin{array}{c}\text { Path } \\
\text { Coefficient }\end{array}$ & $\begin{array}{c}\text { t- } \\
\text { Statistics }\end{array}$ & $\begin{array}{c}\text { p- } \\
\text { Values }\end{array}$ \\
\hline H4 & $\begin{array}{c}\text { Job Stress } \rightarrow \text { Job } \\
\text { Satisfaction } \rightarrow \\
\text { Turnover Intention } \\
\text { Workload } \rightarrow \text { Job } \\
\text { H5 }\end{array}$ & 0.411 & 2.561 & 0.001 \\
& $\begin{array}{c}\text { Satisfaction } \rightarrow \\
\text { Turnover Intention }\end{array}$ & 0.296 & 3.110 & 0.001 \\
\hline
\end{tabular}

\section{Coefficients of Determination (R2)}

The decision coefficient (R2 values) and direction coefficients (beta values) were criteria for evaluating how well the hypothesized relationships were supported by the evidence (Hair Jr et al., 2017). R2 is rated as .250 (weak), .500 (moderate) and .750 (substantial). R2 was identified as a moderate value of .509 . Therefore, the outcomes should be considered important to revenue success [77], [88], [91].

\section{Discussion AND CONCLUSION}

Hypothesis 1a predicted that job stress positively influences turnover intention. The results of testing the structural equation model presented a significant effect of organizational commitment on turnover intention, as shown in Table III $(\beta=0.421, p<0.000)$. Accordingly, hypothesis 1a was accepted. Hypothesis $1 \mathrm{~b}$ projected that job stress positively influences job satisfaction. The results of testing the structural equation model indicated an insignificant influence of satisfaction with job stress to job satisfaction, as il-lustrated in Table III $(\beta=0.299, \mathrm{p}>0.010)$. Therefore, Hypothesis $2 \mathrm{~b}$ was accepted. Hypothesis $2 \mathrm{a}$ predicted that workload positively influences turnover intention. The results of testing the structural equation model illustrated a significant influence of workload to turnover intention, as depicted in Table III $(\beta=0.325, p<0.020)$. Consequently, the results led to the acceptance of Hypothesis $2 \mathrm{a}$. Hypothesis $2 \mathrm{~b}$ stated that satisfaction with workload positively influences job satisfaction. The results of testing the structural equation model showed a significant influence of workload positively influences Job Satisfaction, as described in Table III ( $\beta=$ $0.158, \mathrm{p}>0.02)$. Therefore, the results led to the accepted of Hypothesis 2b. Hypothesis 3 showed that job satisfaction positively influences turnover intention. The results of testing the structural equation model indicated an insignificant effect of satisfaction with supervision on organizational commitment, as shown in Table III $(\beta=0.211, \mathrm{p}>0.020)$. Accordingly, Hypothesis 3 was accepted. Hypothesis 4 and 5 stated that job satisfaction mediated the relationship between job stress, workload, and turnover intention. Results showed that both Hypothesis (i.e., H4, H5) indicating a partial mediation since $\mathrm{H} 3$ and $\mathrm{H} 4$ was found to accept the direct impact on turnover intention as shown in Table IV. 


\section{CONCLUSIONS}

This study aimed to test the mediating effect of job satisfaction on the relationship between job stress, workload, and turnover intentions. The results showed that job stress and workload have a significant positive effect on turnover intentions. This study further concludes that academic and management staff in universities faces two major problems: job stress and workload. Research shows differences in the perception of academic stressors and psychophysiological responses of stress based on different profiles of emotional regulation [92]. Psychological support or training coping strategies can help to manage uncertainty and stress and maintain adequate levels of well-being, physical and mental health [93]. Both these problems bear with negative effects on performance and output of employees' turnover. Since the job stress and workload values are found to be negatively associated with job satisfaction. Therefore, it is concluded that job satisfaction is negatively associated with turnover intention. Therefore, top leadership in the education sector must focus of making sure to satisfy the needs of the employees to make sure that they are not leaving the organization soon. These results reflect the importance of this study and its consequent impact on the literature.

Job satisfaction is impressed by job stress and workload, while job satisfaction does not predispose turnover intention either directly or indirectly, to reduce the grade of turnover intention in the universities. Openness in terms of the work responsibilities di-vision to employees, especially for young employees, at that age the grade of desire to get a better career path is very large, the need for a sense of security in the enterprise becomes important for them to stay afloat. Job satisfaction consists of various supporting elements, one of which is a comfortable work environment by providing space to innovate, so that employees can improve their performance which can then increase job satisfaction and reduce the intention to move. For result that show job satisfaction has negative impact on turnover intention, the universities must create a comfortable work environment and clarity in terms of the responsibilities, which can be done with all staff every two or three months, where university-to-employee communication and vice versa can be enabled, with employees asking anything as desired. The result of this research shows that job satisfaction in fact does mediate turnover intention, and companies need to increase employees' linkages to departmental or university policies. Such a change of rewards could come, e.g., in the form of money being replaced with vacation trips in order to increase employee enthusiasm.

\section{LIMITATIONS \& FUTURE RESEARCH}

This study is limited to the geographical boundaries of Malaysia. Therefore, this study provides minimal generalizability of results on a global scale. Future research could include similar studies conducted in other parts of the country or in new regions and cultures such as Austria, Italy, or Spain as this could give more insight into the theoretic construct. Furthermore, there is a need to test the role of other variables in the relationship between turnover intentions. In this regard, it is suggested that the role of job satisfaction and perceived employment opportunity should be tested. It is also suggested that this study should also be conducted by researchers in others business sectors. For further research can improve this study by adding research variables, such as, organizational commitment, organizational culture, and other variables in examining the factors that influence turnover intention. Researchers may also use other methods in researching turnover intention to obtain more varied results.

\section{FUNDING:}

This research received no external funding.

\section{CONFLICTS OF INTEREST}

The authors declare no conflict of interest.

\section{REFERENCES}

[1] Wesley R. Pieters, Ebben van Zyl, Petrus Ne. Testing a model of turnover intention: Lecturers at the University of Namibia. SA Journal of Human Resource Management. 2020, 18(0), 1683-7584.

[2] Sawahel, W. (2017). Cooperation the magic word for academic libraries. University World News. Retrieved from http://www.universityworldnews.com/article.php?story $1 / 42017012$ 3113120770.

[3] Theron M., Barkhuizen, N., Plessis, Y. D. Managing the academic talent void: Investigating factors in academic turnover and retention in South Africa. SA Journal of Industrial Psychology. 2014, 40 (1), 20710763.

[4] Wazir H, Jan I. Moderating effects of organizational commitment on job satisfaction and turnover intention. Journal of Research in Emerging Markets. 2020 Sep 30;2(4): 48-57.

[5] Agarwal, P., \& Sajid, S. M. A study of job satisfaction, organizational commitment and turnover intention among public and private sector employees. J. Managem.Research. 2017, 17 (3), 123-136.

[6] Özgeldi, M., \& Elif, H.The Effects of Organizational Trust on Turnover intention. Financial and Credit Activity Problems of Theory and Practice, 2019, 488-494.

[7] Tett, R. P., Meyer, J. P. Job satisfaction, organizational commitment, turnover intention and turnover: Path analyses based on meta-analytic findings. Personal Psychology, 1993, 46, 259-291.

[8] Bluedorn AC. A unified model of turnover from organizations. Human relations. $1982 \mathrm{Feb} ; 35(2): 135-53$.

[9] Kim, S. Y., \& Fernandez, S. Employee empowerment and turnover intention in the US federal bureaucracy. Amer. Rev. Publ. Admin., 2017, 47(1), 4-22.

[10] Reina, C. S., Rogers, K. M., Peterson, S. J., Byron, K., \& Hom, P. W. (2018). Quitting the boss? The role of manager influence tactics and employee emotional engagement in voluntary turnover. J. Leaders. Organ. Stud., 2018, 25(1), 5-18.

[11] Hancock, J. I., Allen, D. G., Bosco, F. A., McDaniel, K. R. and Pierce, C. A., "Meta-analytic review of employee turnover as a predictor of firm performance", Journal of Management, 2013. Vol. 39 No. 3, pp. 573-603.

[12] Scanlan JN, Still M. Job satisfaction, burnout and turnover intention in occupational therapists working in mental health. Australian occupational therapy journal. 2013 Oct;60(5):310-8.

[13] Pardiman, P. The effect of social capital and organizational commitment toward lecturer performance with islamic work ethics as a moderating role. JEMA: Jurnal Ilmiah Bidang Akuntansi Dan Manajemen, 2018. 15(1), 12-26.

[14] Yu, J.; Ariza-Montes, A.; Giorgi, G.; Lee, A.; Han, H. Sustainable Relationship Development between Hotel Company and Its Employees: Linking Job Embeddedness, Job Satisfaction, SelfEfficacy, Job Performance, Work Engagement, and Turnover. Sustainability 2020, 12, 7168. https://doi.org/10.3390/su12177168.

[15] Dipboye RL. Social Structures in Organizations. InThe Emerald Review of Industrial and Organizational Psychology 2018 Aug 13. Emerald Publishing Limited.

[16] Darwis D, Badeni B, Danim S. Developing Model of Quality Assurance for Higher Education Institutes. In1st Yogyakarta International Conference on Educational Management/Administration 
and Pedagogy (YICEMAP 2017) 2017 May (pp. 393-399). Atlantis Press.

[17] Ji-Young and Wang, Chaoyu. Job stress and turnover intention revisited: evidence from Korean firms. Problems and Perspectives in Management, 2019. 7(4), 52-61.

[18] Kern JH, Grandey AA. Customer incivility as a social stressor: the role of race and racial identity for service employees. Journal of occupational health psychology. 2009 Jan;14(1):46.

[19] Meier, L. L., \& Semmer, N. K. Lack of reciprocity, narcissism, anger, and instigated workplace incivility: A moderated mediation model. European Journal of Work and Organizational Psychology, 2013. 22(4), 461-475. doi:10.1080/1359432x.2012.654605.

[20] McGrath, J. (1976). Stress and Behaviour in Organization. In Dunnette, M. D. (Ed.), Handbook of Industrial and Organizational Psychology (pp. 1351-1395) Chicago: Rand McNally.

[21] Petrus V. M., Siti E. A., Kusdi R., \& Andriani K. (2018). The Influence of Spiritual Intelligence on Job Stress and Turnover Intention. Russian Journal of Agricultural and Socio-Economic Sciences. 11(83), 243253.

[22] Davis, K., \& Newstrom, J.W. Human Behavior at Work: Organizational Behavior, Seventh edition. New York: McGraw Hills. (1985).

[23] Imran B, Mariam S, Aryani F, Ramli AH. Job Stress, Job Satisfaction and Turnover Intention. InInternational Conference on Management, Accounting, and Economy (ICMAE 2020) 2020 Sep 15 (pp. 290-292). Atlantis Press.

[24] Zhang W, Meng H, Yang S, Liu D. The influence of professional identity, job satisfaction, and work engagement on turnover intention among township health inspectors in China. International journal of environmental research and public health. 2018 May;15(5):988.

[25] Beehr TA, Gupta N. A note on the structure of employee withdrawal. Organizational behavior and human performance. 1978 Feb 1;21(1):73-9.

[26] Liu W, Zhao S, Shi L, Zhang Z, Liu X, Li L, Duan X, Li G, Lou F, Jia $\mathrm{X}$, Fan L. Workplace violence, job satisfaction, burnout, perceived organisational support and their effects on turnover intention among Chinese nurses in tertiary hospitals: a cross-sectional study. BMJ open. 2018 Jun 1;8(6). 019525.

[27] Puangyoykeaw K, Nishide Y. Organizational commitment and turnover intention in low-skilled immigrant workers in Thailand: An empirical assessment of need satisfaction, job satisfaction and overall life satisfaction factors. International Journal of Business and Management. 2015 Mar 1;10(5):98.

[28] Rizwan M, Arshad MQ, Munir HM, Iqbal F, Hussain A. Determinants of Employees intention to leave: A Study from Pakistan. International Journal of Human Resource Studies. 2014 Jul 1;4(3):1-8.

[29] Nideffer, R. M. Test of attentional and interpersonal style. Journal of Personality and Social Psychology, 1976. 34(3), 394404. doi:10.1037/0022-3514.34.3.394.

[30] Riggio RE, Riggio HR, Salinas C, Cole EJ. The role of social and emotional communication skills in leader emergence and effectiveness. Group Dynamics: Theory, Research, and Practice. 2003 Jun;7(2):83.

[31] Mackill DJ, Ismail AM, Pamplona AM, Sanchez DL, Carandang JJ, Septiningsih EM. Stress tolerant rice varieties for adaptation to a changing climate. Crop, Environment \& Bioinformatics. 2010 Dec 1;7:250-9.

[32] Pache AC, Santos F. When worlds collide: The internal dynamics of organizational responses to conflicting institutional demands. Academy of management review. $2010 \mathrm{Jul} ; 35(3): 455-76$.

[33] Lau Y. The effect of maternal stress and health-related quality of life on birth outcomes among Macao Chinese pregnant women. The Journal of perinatal \& neonatal nursing. 2013 Jan 1;27(1):14-24.

[34] Moghissi ES, Korytkowski MT, DiNardo M, Einhorn D, Hellman R, Hirsch IB, Inzucchi SE, Ismail-Beigi F, Kirkman MS, Umpierrez GE. American Association of Clinical Endocrinologists and American Diabetes Association consensus statement on inpatient glycemic control. Diabetes care. 2009 Jun 1;32(6):1119-31.

[35] Pache AC, Santos F. When worlds collide: The internal dynamics of organizational responses to conflicting institutional demands. Academy of management review. $2010 \mathrm{Jul} ; 35(3): 455-76$.

[36] Petersen PE. World Health Organization global policy for improvement of oral health-World Health Assembly 2007 International dental journal. 2008 Jun 1;58(3):115-21.

[37] Ekpenyong CE, Inyang UC. Associations between worker characteristics, workplace factors, and work-related musculoskeletal disorders: a cross-sectional study of male construction workers in Nigeria. International Journal of Occupational Safety and Ergonomics. 2014 Jan 1;20(3):447-62.

[38] Vijayalakshmi P, Pashupu DR, Thimmaiah R, Math SB. Nurses attitudes and perceptions of nursing research: an Indian perspective.
Asian Journal of Nursing Education and Research. 2014 Oct $1 ; 4(4): 509$.

[39] Cullen KL, Edwards BD, Casper WC, Gue KR. Employees' adaptability and perceptions of change-related uncertainty: Implications for perceived organizational support, job satisfaction, and performance. Journal of Business and Psychology. 2014 Jun 1;29(2):269-80.

[40] Ismail A, Ghani AB, Subhan M, Joarder MH, Ridzuan AA. The relationship between stress and job satisfaction: an evidence from Malaysian peacekeeping mission. Mediterranean Journal of Social Sciences. 2015 Aug 18;6(4):647.

[41] Lazrus, R. S. (2013). Psychological Stress in the Workplace. Fifty Years of the Research and Theory of RS Lazarus: An Analysis of Historical and Perennial Issues, 312.

[42] Millward LJ, Postmes T. Who we are affects how we do: The financial benefits of organizational identification. British Journal of Management. 2010 Jun;21(2):327-39.

[43] Rodriguez D, Buyens D, Van Landeghem H, Lasio V. Impact of lean production on perceived job autonomy and job satisfaction: An experimental study. Human factors and ergonomics in manufacturing \& service industries. $2016 \mathrm{Mar} ; 26(2): 159-76$.

[44] Bottonari KA, Roberts JE, Kelly MA, Kashdan TB, Ciesla JA. A prospective investigation of the impact of attachment style on stress generation among clinically depressed individuals. Behaviour Research and Therapy. 2007 Jan 1;45(1):179-88.

[45] Ahsan N, Abdullah Z, Fie DY, Alam SS. A study of job stress on job satisfaction among university staff in Malaysia: Empirical study. European journal of social sciences. 2009 Mar;8(1):121-31.

[46] Smith A.P., \& Smith H. N. (2017). Workload, Fatigue and Performance in the Rail Industry. In: Longo L., Leva M. (eds) Human Mental Workload: Models and Applications. H-WORKLOAD 2017 Communications in Computer and Information Science, Vol. 726. Springer, Cham. https://doi.org/10.1007/978-3-319-61061-0_17.

[47] Arshad MZ, Shahidan AN, Ibrahim Siam IM, Alshuaibi AS. Effect of Role Conflict and Work Overload on Job Stress: A Case of Banking Sector Employees. Talent Development \& Excellence. 2020 Mar 2;12.

[48] Tham P, Meagher G. Working in human services: How do experiences and working conditions in child welfare social work compare? British Journal of Social Work. 2009 Jul 1;39(5):807-27.

[49] Lee E, Jang I. Nurses' fatigue, job stress, organizational culture, and turnover intention: A Culture-Work Health model. Western journal of nursing research. $2020 \mathrm{Feb} ; 42(2): 108-16$.

[50] Masta, N., \& Riyanto, S. (2020). The Effect of Transformational Leadership, Perceived Organizational Support and Workload on Turnover Intention Sharia Banking Company in Jakarta. Saudi Journal of Business and Management Studies. Vol. 5(8): 473-481.

[51] Rizka, F. M., Ardiana, I. D. K. R., \& Andjarwati, T. (2020). The Effect of Workload, Pay Satisfaction, Work Satisfaction on Turnover Intention, and Performance of Employees of Angkasa Pura Logistic Indonesia. International Journal of Social Science and Economics Invention, 06(02), 234-241.

[52] Suarthana, J. H. P., \& Riana, I. G. (2016). The Effect of Psychological Contract Breach and Workload on Intention to Leave: Mediating Role of Job Stress. Procedia - Social and Behavioral Sciences, 219, 717-723.

[53] Tulangow, M. J., Saerang, D. P. E., \& Rumokoy, F. S. (2018). The Effect of Job Stress, Work Environment, and Workload on Employee Turnover Intention (Case Study at PT. Wika Reality Manado). Journal EMBA, 6(2), 474-482.

[54] Hart, S. M., \& Warren, A. M. (2015). Understanding nurses' work: Exploring the links between changing work, labour relations, workload, stress, retention and recruitment. Economic and Industrial Democracy, 36(2), 305-329.

[55] Seo Y, Ko J, Price JL. The determinants of job satisfaction among hospital nurses: a model estimation in Korea. International journal of nursing studies. 2004 May 1;41(4):437-46.

[56] Xiaoming, Y., Ma, B. J., Chang, C. L., \& Shieh, C. J., (2014). Effects of Workload on Burnout and Turnover Intention of Medical Staff: A Study. Studies on Ethno-Medicine. Vol. 8(3), 229-237. DOI: 10.31901/24566772.2014/08.03.04

[57] Zhang Y, Kumada T. Relationship between workload and mindwandering in simulated driving. PloS one. 2017 May 3;12(5):e0176962.

[58] Tentama F, Rahmawati P, Muhopilah P. The effect and implications of work stress and workload on job satisfaction. International Journal of Scientific and Technology Research. 2019;8(11):2498-502.

[59] Fazey, M. (2013). Human Resource Policy: Connecting Strategy with Real-world Practice. Australia: Tilde Publishing and Distribution.

[60] Thomas J, Noel-Storr A, Marshall I, Wallace B, McDonald S, Mavergames C, Glasziou P, Shemilt I, Synnot A, Turner T, Elliott J. 
Living systematic reviews: 2. Combining human and machine effort. Journal of clinical epidemiology. 2017 Nov 1;91:31-7.

[61] Beaven, K. (2019). Strategic Human Resource Management: An HR Professional's Toolkit. London: Kogan Page, Limited.

[62] Darwish, T. K., \& Fattaah, P. M. A. (2020). Human Resource Management in an Emerging South Asian Economy: The Case of Brunei. New York: Routledge.

[63] Klussmann A, Liebers F, Brandstädt F, Schust M, Serafin P, Schäfer A, Gebhardt H, Hartmann B, Steinberg U. Validation of newly developed and redesigned key indicator methods for assessment of different working conditions with physical workloads based on mixedmethods design: a study protocol. BMJ open. 2017 Aug $1 ; 7(8): \mathrm{e} 015412$.

[64] Hilma H, Amanah D, Harahap DA. The Workload and organizational commitment to job satisfaction. The International Journal of Humanities \& Social Studies. 2020 Jun 8;6: 30-33.

[65] Dipboye RL. Structured and unstructured selection interviews: Beyond the job-fit model. Research in personnel and human resources management. 1994;12:79-123.

[66] Dwiyanti R, Hamzah HB, Abas NB. Job satisfaction, psychological contracts, and turnover intention: Role of social support as a mediator. International Journal of Research in Business and Social Science (2147-4478). 2019 Oct 20;8(6):96-104.

[67] Ramli AH. Work environment, job satisfaction and employee performance in health services. Business and Entrepreneurial Review. 2019 Aug 24;19(1):29-42.

[68] Lambert EG, Qureshi H, Frank J, Klahm C, Smith B. Job stress, job involvement, job satisfaction, and organizational commitment and their associations with job burnout among Indian police officers: A research note. Journal of Police and Criminal Psychology. 2018 Jun;33(2):8599.

[69] Kim MJ, Han JY. Effect of head nurses' authentic leadership on nurses' job satisfaction and nursing performance: Focusing on the mediating effects of empowerment. Journal of Korean Academy of Nursing Administration. 2019 Jan 1;25(1):25-34.

[70] Rothmann, S., Diedericks, E., \& Swart, J. P. (2013). Manager relations, psychological need satisfaction and intention to leave in the agricultural sector. South African Journal of Industrial Psychology, 39(2), 1-14.

[71] Ahmad, B., Shahid, M., Huma, Z., \& Haider, S. (2012). Turnover intention: An HRM issue in the textile sector. Interdisciplinary Journal of Contemporary Research in Business, 3(12), 125-130.

[72] Ahn, J. Y., Chaoyu, W. (2019). Job stress and turnover intention revisited: evidence from Korean firms. Problems and Perspectives in Management, Vol. 17 (4), 52-61.

[73] Griffeth RW, Hom PW, Gaertner S. A meta-analysis of antecedents and correlates of employee turnover: Update, moderator tests, and research implications for the next millennium. Journal of management. 2000 Jun;26(3):463-88.

[74] Duraisingam V, Pidd K, Roche AM. The impact of work stress and job satisfaction on turnover intentions: A study of Australian specialist alcohol and other drug workers. Drugs: education, prevention and policy. 2009 Jan 1;16(3):217-31.

[75] Victor B, Cullen JB. The organizational bases of ethical work climates. Administrative science quarterly. 1988 Mar 1:101-25.

[76] Koskenvuori, J., Numminen, O., \& Suhonen, R. (2019). Ethical climate in nursing environment: A scoping review. Nurs Ethics. 26: 327-345.

[77] Anjum, T., Amoozegar, A., Nazar, N., \& Kanwal, N. (2020). Intervening effect of attitudes towards entrepreneurship: Correlation between passion and entrepreneurial intention. International Journal of Advanced Science and Technology, 29(5 Special Issue), 1327-1340.

[78] Anjum, T., Ramzani, S. R., \& Farrukh, M. (2018). Entrepreneurial Intentions of Pakistani Students: The Role of Entrepreneurial Education, Creativity Disposition, Invention Passion \& Passion for Founding. Journal of Management Research, 10(3), 76-100 https://doi.org/10.5296/jmr.v10i3.13253

[79] Anjum, T., Ramzani, S. R., \& Nazar, N. (2019). Antecedents of Entrepreneurial Intentions: A Study of Business Students from Universities of Pakistan. International Journal of Business and Psychology, 1(2), 72-88.

[80] Anjum, T., Ramzani, S.R., Nazar, N., Shahzad, I.A. and Salman, S. (2018). Entrepreneurial Intention: Does Entrepreneurial Education Matter in Pakistan? International Journal of Human Resource Studies, 8(3), 147-161. https://doi.org/10.5296/ijhrs.v8i3.13213.

[81] Anees, R. T., Nordin, N. A., Anjum, T., Cavaliere, L. P. L., \& Heidler, P. (2020). Evaluating the Impact of Customer Relationship Management (CRM) Strategies on Customer Retention (A Study of Fast Food Chains in Pakistan). Business Management and Strategy, 11(2), 117-133. https://doi.org/10.5296/bms.v11i2.17934.
[82] Anderson, J. C., \& Gerbing, D. W. (1988). Structural equation modeling in practice: A review and recommended two-step approach. Psychological Bulletin, 103(3), 411

[83] Anjum, T., Farrukh, M., Heidler, P., \& Tautiva, J. A. D. (2021). Entrepreneurial Intention: Creativity, Entrepreneurship, and University Support. J. Open Innov. Technol. Mark. Complex, 7(1), 1-13.

[84] Farrukh, M., Lee, J. W. C., Sajid, M., \& Waheed, A. (2019). Entrepreneurial intentions: The role of individualism and collectivism in perspective of theory of planned behaviour. Education+Training.

[85] Anees R. T., Raju V, Cavaliere LP, Heidler P, Nordin N.A. The Effect of Emotional Intelligence and Market Orientation on Sales Performance: The Moderating Role of Entrepreneurial Orientation. PalArch's Journal of Archaeology of Egypt/Egyptology. 2020 Nov 28; 17(7):6377-97.

[86] Zreen, A., Farrukh, M., Nazar, N., \& Khalid, R. (2019). The Role of Internship and Business Incubation Programs in Forming Entrepreneurial Intentions: An Empirical Analysis from Pakistan. Journal of Management and Business Administration. Central Europe, 27(2), 97-113.

[87] Hair Jr, J. F., Hult, G. T. M., Ringle, C., \& Sarstedt, M. (2017). A primer on partial least squares structural equation modeling (PLSSEM). Sage Publications.

[88] Chin, W. W. (1998). Modern Methods for Business Research. Modern Methods for Business Research. https://doi.org/10.4324/9781410604385.

[89] Hair Jr, J. F., Sarstedt, M., Ringle, C. M., \& Gudergan, S. P. (2017). Advanced issues in partial least squares structural equation modeling, pp. 1-5. Sage Publications: Los Angeles, CA.

[90] Fornell, C., \& Larcker, D. F. (1981). Structural Equation Models with Unobservable Variables and Measurement Error: Algebra and Statistics. Journal of Marketing Research, 18(3), 382. https://doi.org/10.2307/3150980.

[91] Anees, R. T., Raju, D. V., \& Anjum, T. (2020). A Mediating Role of Adaptive Selling Behavior: Relationship between Emotional Intelligence and Sales Performance. Beverage Industry of Pakistan. International Journal of Psychosocial Rehabilitation, 24(1), 52665275 .

[92] Saeed Muhammad, Temoor Anjum, Fahad Khan Afridi, D. I. I. A. (2020). Impact of Transformational Leadership on Project Success Criteria: The Moderating Role of Work Engagement. Palarch's Journal of Archaeology of Egypt/Egyptology, 17(6), 7460-7476.

[93] Morales-Rodríguez FM, Pérez-Mármol JM. The Role of Anxiety, Coping Strategies, and Emotional Intelligence on General Perceived Self-Efficacy in University Students. Front Psychol. 2019;10:1689.

[94] Alcover C-M, Salgado S, Nazar G, Ramírez-Vielma R, González-Suhr C. Job insecurity, financial threat and mental health in the COVID-19 context: The buffer role of perceived social support. medRxiv. 1. Januar 2020;2020.07.31.20165910. 